\title{
Concomitant production of gum, nut and peduncle in dwarf cashew tree explored under different levels of irrigation and fertilization
}

\author{
Reivany Eduardo Morais Lima*1, Laíse Ferreira de Araújo', \\ Josivavia Rodrigues Barros', Marlos Alves Bezerra² \\ 'Federal University of Ceará, Fortaleza, Brazi \\ ${ }^{2}$ Brazilian Agricultural Research Corporation, Embrapa Agroindústria Tropical, Fortaleza, Brazil \\ *Corresponding author, e-mail: reivany_eduardo@hotmail.com
}

\begin{abstract}
The main goal of this innovator study was to evaluate if the gum extraction influences the production of nut and peduncle of precocious dwarf cashew tree grown under different water regimes and mineral nutrition. Adult trees of CCP-76 clone were submitted to water regimes: irrigated $1100 \%$ da ETPC) and non-irrigated, and three fertilization levels with NK: $50 \%, 100 \%$ and $150 \%$ of the recommended for the crop nutrition. Additionally was added a treatment in which the gum was not extracted from plants (control). The extraction of gum was performed monthly during a period of 15 months, while the nut and peduncle were collected at the end of the cropping season, after the gum extraction period. The quality of the peduncle was determined by the soluble solids content (SSP). The production of gum in the first semester of the year followed an increasing trend on every three months, regardless the water regime. In the second semester, an interaction between the factors was observed, with irrigated plants producing more gum in higher fertilizer levels (100 and $150 \%)$, while in the non-irrigated conditions, the highest gum production occurred with the lower fertilization level (50\%). The production of nut and peduncle were not affected by treatments or gum extraction. The highest contents of SSP was observed when the plants were irrigated.
\end{abstract}

Keywords: Cashew resin, mineral nutrition, water regime

\section{Produção concomitante de goma, castanha e pedúnculo em plantas de cajueiro anão exploradas sob diferentes níveis de irrigação e adubação}

\begin{abstract}
Resumo
O objetivo desse estudo inovador foi avaliar se a coleta de goma influencia a produção de castanha e pedúnculo de plantas de cajueiro anão precoce cultivadas sob diferentes regimes hídricos e de nutrição mineral. Plantas adultas do clone CCP-76 foram submetidas aos regimes hídricos irrigado (100\% da ETc) e sequeiro e três níveis de adubação com NK: 50\%, 100\% e 150\% recomendado na nutrição da cultura. Adicionalmente foi inserido um tratamento no qual não se coletou a goma das plantas. A coleta da goma foi realizada mensalmente por um período de 15 meses, enquanto as castanhas e pedúnculos foram coletados ao fim do período de safra, após o período de extração da goma. A qualidade do pedúnculo foi determinada pelo teor de sólidos solúveis (SSP). A produção de goma no primeiro semestre do ano seguiu uma tendência crescente a cada três meses, independente do regime hídrico. No segundo semestre, houve interação entre os fatores, com as plantas irrigadas produzindo mais goma nos maiores níveis de adubação (100 e $150 \%$ ) enquanto sob condições de sequeiro a maior produção de goma ocorreu no menor nível de adubação (50\%). As produções de castanha e de pedúnculo não foram afetadas pelos tratamentos ou extração da goma. O SSP apresentou maiores teores quando as planta foram irrigadas.
\end{abstract}

Palavras chave: Resina de cajueiro, nutrição mineral, regime hídrico 


\section{Introduction}

The Northeast of Brazil, with $99 \%$ of the cashew cultivation area of the country, projects its orchard primarily for obtaining cashew nut's almond (Oliveira, 2008). However, for the cashew crop becomes a more profitable and sustainable activity, being necessary to take full advantage of the cashew co-products such as the cashew gum (resin), since it is cultivated in a large area and due to the similar aspect with Arabic gum.

The Arabic gum has broad relevance in the food (Chen et al., 2015; Khalid et al., 2014), pharmaceutical (Musa et al., 2015) and cosmetic industry (Khaliq et al., 2015). Polysaccharides such as Arabic gum, cashew gum and others can still move numerous research papers, involving studies of extraction, identification and characterization processes, properties, biological activities and applications (Yang \& Zhang, 2009).

Considering an average production of cashew of $700 \mathrm{~g}$ gum.plant ${ }^{-1}$.year ${ }^{-1}$ in Brazil (Bandeira, 1991), and extrapolating this data to the area planted with cashew in Northeastern of Brazil, the amount produced would be higher than the Arabic gum importation in 2011 (1.360 tons), providing a reduction in the cost of importation of Arabic gum and even allowing Brazil to export this material, increasing its commercial income in the export sector.

Despite the fact that dwarf cashew is a semi-arid climate crop, with little water requirement, the use of irrigation allows the improvement in the cashew nut and peduncle production (Lima et al., 2010) and, perhaps, this water application can influence the production of cashew gum. Another important factor for improving productivity is soil fertility, that can define the conditions for the mineral nutrients supply, which, under appropriate conditions, provides higher yield and quality(Melém Junior et al., 2008).

According to the exposed, the main goal of this innovator study was to evaluate the gum production and its influence in the pseudofruit (peduncle) and fruits (nuts) productions in precocious dwarf cashew trees grown under two water regimes and three different levels of mineral nutrition (fertilization levels).

\section{Material and Methods}

The experiment was conducted at Embrapa Tropical Agroindustry, Experimental Pacajus Station, at the coordinates $4^{\circ} 10^{\prime} \mathrm{S}$, $38^{\circ} 27^{\prime} \mathrm{W}$ and altitude of $60 \mathrm{~m}$, state of Ceará, Brazil, with a climate classified as Aw, according to Köppen. The rainfall during the experimental evaluation period was $652.4 \mathrm{~mm}$. The experimental area used was 0.59 ha, with 120 adult trees of precocious dwarf cashew 18 years old), CCP-76 clone (grafted with the CCP06 clone rootstock), spaced 7 meters between plants and rows.

The plants were submitted to two different waterregimes (WR): Irrigated (100\% of the potential crop evapotranspiration - ETPC), non-irrigated ( $0 \%$ of ETPC) and three different fertilization levels (FL) with NK: $50 \%$ of the recommended conventional nutrition (fertilization), $100 \%$ of the recommended conventional nutrition and $150 \%$ of the recommended conventional nutrition of the crop, configuring the $2 \times 3$ factorial design , with six treatments, wherein the first factor is related tothe presence or absence of irrigation (WR), and the second factor regarding the three different fertilization levels with NK (FL), with five repetitions (each one with four representative trees). To evaluate the influence of gum production in the nut and peduncle production, an additional portion with five replications (20 trees) was considered, wherein the trees were not explored regarding the gum extraction (Control).

The fertilization was performed according Crisóstomo et al. (2009) based on soil analysis (Table 1). The sources of macronutrients used were: Urea for nitrogen (N), single superphosphate for phosphorus (P) and potassium chloride for potassium (K). The micronutrients were used in the form of FTE BR-12. The two macronutrients $\mathrm{N}$ and $\mathrm{K}$ were fractionated according to the fertilization levels of the treatments and applied in three portions with intervals of fifteen days, while $P$ and the micronutrients FTE BR-12 were applied once. The application of dolomitic calcareous was performed two months before the implementation of the first factor.

The localized irrigation system was used with micro-sprinklers, with a single micro-sprinkler self-compensating per plant, presented $93.4 \%$ 
of uniformity of distribution and 37.1 L.h-1 for the average flow rate of the emitter with $2.8 \mathrm{~m}$ of hydraulic radius. To obtain the amount of water to be applied per plant with two days of irrigation interval, the methodology described by Oliveira et al. (2003) was followed (Table 2).

Table 1. Soil analysis of the experimental area

\begin{tabular}{|c|c|c|c|c|c|c|c|c|}
\hline $\mathrm{pH}$ & E.C. & $\mathrm{Ca}^{\prime}$ & $\mathrm{Mg}^{1}$ & $\mathrm{~K}^{1}$ & $\mathrm{Na}^{1}$ & S.B. & $\mathrm{Al}^{1}$ & $\mathrm{H}+\mathrm{Al}^{\prime}$ \\
\hline 5.76 & 0.26 & 7.33 & 3.9 & 1.5 & 0.97 & 13.77 & - & 15.3 \\
\hline C.E.C. & $\mathrm{V}$ & O.M. & $P^{2}$ & $\mathrm{~S}^{2}$ & $\mathrm{Cu}^{2}$ & $\mathrm{Fe}^{2}$ & $M n^{2}$ & $Z n^{2}$ \\
\hline 29.03 & 47.3 & 5.7 & 2.77 & - & 0.2 & 4.97 & 5.93 & 8.43 \\
\hline
\end{tabular}

Table 2. Data used to prepare the irrigation calendar

\begin{tabular}{|c|c|c|c|c|c|c|c|c|}
\hline Month & E†o* & E†०* & $\mathrm{KC}^{*}$ & ETpc & $\mathrm{Kr} *$ & A & DV & OPS \\
\hline Oct.12 & 200.80 & 6.48 & 0.65 & 4.21 & 0.76 & 28.26 & 90.43 & $04: 50$ \\
\hline Nov.12 & 189.44 & 6.31 & 0.65 & 4.10 & 0.76 & 28.26 & 88.16 & $04: 45$ \\
\hline Dec.12 & 195.12 & 6.29 & 0.65 & 4.09 & 0.76 & 28.26 & 87.87 & $04: 45$ \\
\hline Jan.13 & 164.72 & 5.31 & 0.65 & 3.45 & 0.76 & 28.26 & 74.18 & 04:00 \\
\hline Feb.13 & 144.72 & 5.17 & 0.65 & 3.36 & 0.76 & 28.26 & 72.16 & 04:00 \\
\hline Mar.13 & 133.92 & 4.32 & 0.65 & 2.81 & 0.76 & 28.26 & 60.31 & 03:15 \\
\hline Apr.13 & 126.00 & 4.20 & 0.65 & 2.73 & 0.76 & 28.26 & 58.63 & 03:10 \\
\hline May.13 & 128.00 & 4.13 & 0.65 & 2.68 & 0.76 & 28.26 & 57.64 & 03:05 \\
\hline Jun.13 & 135.04 & 4.50 & 0.65 & 2.93 & 0.76 & 28.26 & 62.84 & 03:25 \\
\hline Jul.13 & 157.60 & 5.08 & 0.65 & 3.30 & 0.76 & 28.26 & 70.97 & 03:50 \\
\hline Aug. 13 & 185.20 & 5.97 & 0.65 & 3.88 & 0.76 & 28.26 & 83.40 & $04: 30$ \\
\hline Sep.13 & 191.60 & 6.39 & 0.65 & 4.15 & 0.76 & 28.26 & 89.16 & 04:50 \\
\hline Oct.13 & 200.80 & 6.48 & 0.65 & 4.21 & 0.76 & 28.26 & 90.43 & 04:50 \\
\hline Nov.13 & 189.44 & 6.31 & 0.65 & 4.10 & 0.76 & 28.26 & 88.16 & 04:45 \\
\hline Dec.13 & 195.12 & 6.29 & 0.65 & 4.09 & 0.76 & 28.26 & 87.87 & $04: 45$ \\
\hline
\end{tabular}

The following variables were evaluated: monthly production of gum, nut and peduncle production and peduncle's soluble solids content for the 2013 crop season, after the gum extraction. The gum extraction period was from October 2012 to December 2013, totaling fifteen months of evaluation for the water regime factor. However, the fertilization factor was only analyzed from February 2013, because the nutrients have been applied in the field at the beginning of the rainfall in the region.

The gum extraction was realized twice a month, according to the following procedure: a single cut was opened at the base of the stem of the trees at a height of approximately $50 \mathrm{~cm}$ from the soil, inclined, descending from left to right, with a length of approximately $20 \mathrm{~cm}$ and thickness of $2 \mathrm{~cm}$, forming an angle of $30^{\circ}$ with the soil. The chemical stimulant Ethrel was used to improve the exudation and stimulate the gum production. Ethrel is a growth regulator of the ethylene group, composed of $24 \% \mathrm{~m} \cdot \mathrm{v}^{-1}$ of acid 2-chloroethylphosphonic (ETHEFON). For each collected gum, the cut was reopened in the top. The software SAS/STAT Version 9.1. was used to generate the analysis of variance and the Tukey's test at $5 \%$ of probability.

\section{Results and Discussion}

Analyzing the monthly gum production according to the water regime factor, it was observed that for the first two extractions (Oct.12 and Nov.12) the non-irrigated cultivation presented a higher production, when compared to the irrigated system. The lower production for the irrigated system is probably due to the fact that plants canmodifythe metabolism by irrigation, presenting higher xylematic and phloematic flows, rather than the flux in the gum resiniferous ducts (Figure 1A).

From the first month of extraction (Oct.12) to the fourth month (Jan.13), the values for gum production decreased, possibly because the fact that the first month of extraction have 
affected the subsequent three months due to the precocious exhaustion of the plants reserves (Figure 1A).

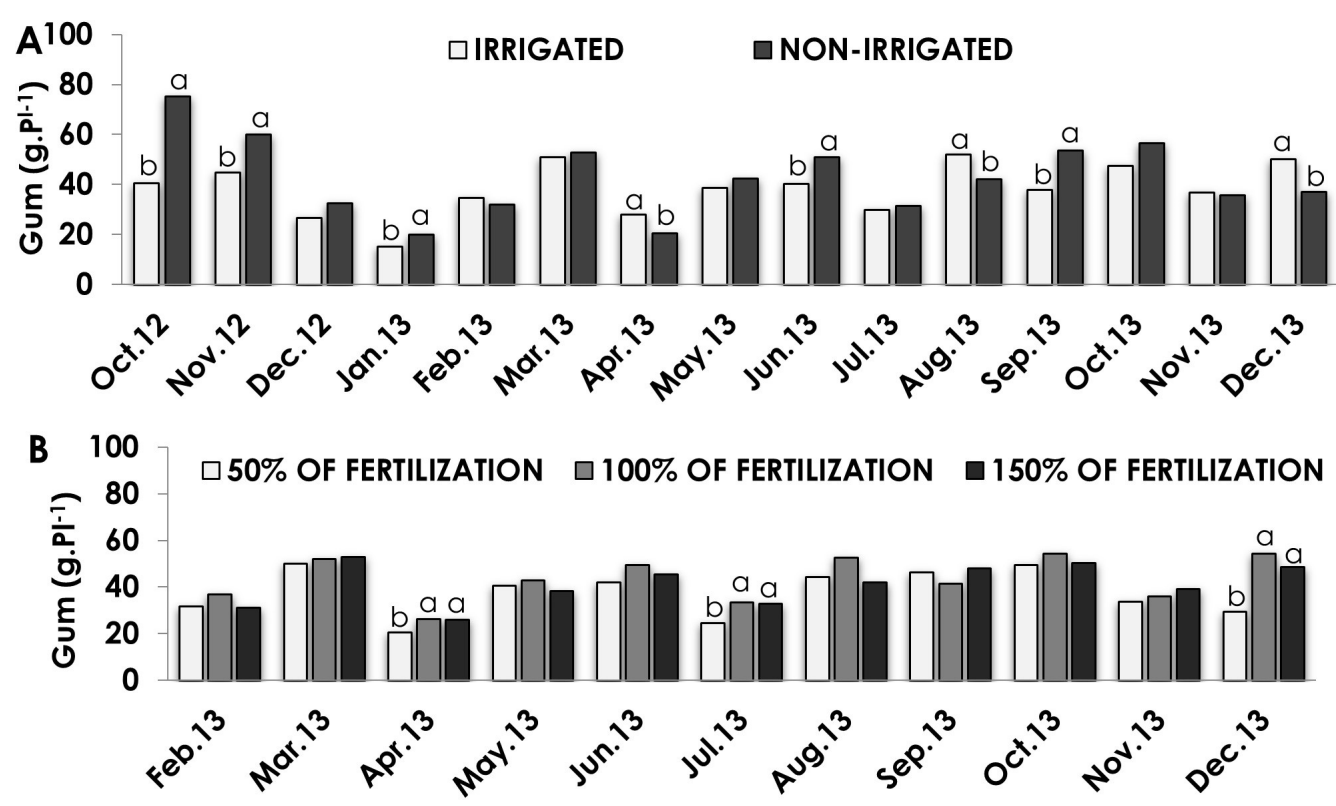

Figure 1. Monthly production of cashew gum per plant grown in irrigated and non-irrigated condition (A), and with $50 \%, 100 \%$ and $150 \%$ of the recommended fertilization (B). Pacajus-CE, Brazil, 2013

In the first semester of 2013 the gum production presented a trend of increase on every three months (Jan.13, Feb.13 and Mar.13, thereafter Apr.13, May.13 and Jun.13), regardless the water regime applied (Figure 1A). The first semester of the year is the rainfall period in region (652.4 mm), indicating that possibly the two systems (irrigated and non-irrigated) presented the same production behavior due to the rainfall influence on the crops cultivated under the nonirrigated system.

During the second semester of the year, in which no rainfall was registered, the plants under irrigated condition tended to alternate its production between the months, in other words, in a month is possible to observe a higher production when compared to the following month, with a lower production, while in nonirrigated condition the trend was a parable with maximum production in September and October (nearly 53 and 56 g. $\mathrm{Pl}^{-1}$, respectively) (Figure 1A).

Corroborating with the informations provided, Lima et al. (2001), evaluating chemical stimulants on the cashew gum extraction, observed higher gum exudation rates in the month of September, with the use of a combined solution of $15 \%$ of Ethephon with $5 \%$ of dimethylsulfoxide. The high exudation rate in this period is probably due to the fact that the plants are in flowering stage and fruit formation, indicating higher production of assimilates in the leaves to ensure the fruit supply.

The average values for gum production were 461.53 and 474.66 g.plant $^{-1}$.year ${ }^{-1}$ for irrigated and non-irrigated conditions, respectively, lower than that founded by Bandeira (1991), who affirmed that the average production of gum per plant during one year is $700 \mathrm{~g}$. The lower production for the present experiment can be explained due to the fact that Bandeira (1991) studied the giant type of the cashew tree, and not the dwarf type. The giant type presents higher size, indicating the presence of largest amounts of carbohydrates reserves, that can be targeted for gum extraction.

According to Mujawamariya \& Karimov (2014), one acacia tree can produce the average of 0,25 to $2 \mathrm{~kg}$ of Arabic gum per year, varying according to the type and climatic conditions. According to the Vellema et al. (2013) the Arabic gum is extracted on every 14 days during the dry season, corresponding from October to June, totaling nine months. During the rainy season, no formation of Arabic gum is 
observed. Interestingly, during the period that no exploration of Arabic gum at the producing areas (Sudan, Nigeria and Kenya) is realized; the production of cashew gum in Brazil is high, indicating that Brazil should be able to export the product.

Analyzing the fertilization level factor, it is possible to observe that for the months in which statistical differences were observed, the level of $50 \%$ of fertilization presented lower yields when compared to other treatments (Figure 1B).

The interaction between the WR and LF factors was observed in the second semester, four months after the application of the two factors together. In the months in which interaction was observed, at the level of $50 \%$ fertilization the gum production was higher for non-irrigated system when compared to irrigated system (Table 3). According to Adam \& Fadl (2011) the gum exudation is subject to drought conditions and these authors indicated the dry seasons of the year to increase the gum production. According to Phillips \& Williams (2000) stress conditions caused by physical injuries, microbial development and other environmental factors can also affect the gum production.

Table 3. Results of gum average production for the months of June, September, October and December 2013 according to the interaction between the factors water regime (WR) and fertilization levels (FL).

\begin{tabular}{|c|c|c|c|}
\hline \multirow[b]{3}{*}{ WR } & \multicolumn{3}{|c|}{ Monthly production of gum (g. $\mathrm{Pl}^{-1}$ ) } \\
\hline & \multicolumn{3}{|c|}{ Jun.13 } \\
\hline & FL 50\% & FL 100\% & FL 150\% \\
\hline Irrigated & $32.66 \mathrm{bA}$ & $40.05 \mathrm{aA}$ & $46.65 \mathrm{aA}$ \\
\hline \multirow[t]{3}{*}{ Non-irrigated } & $51.17 \mathrm{aA}$ & $57.01 \mathrm{aA}$ & $44.32 \mathrm{aA}$ \\
\hline & \multicolumn{3}{|c|}{ Sep.13 } \\
\hline & FL 50\% & FL $100 \%$ & FL $150 \%$ \\
\hline Irrigated & $32.28 \mathrm{bA}$ & $42.69 \mathrm{aA}$ & $37.84 \mathrm{aA}$ \\
\hline \multirow[t]{3}{*}{ Non-irrigated } & $59.50 \mathrm{aA}$ & $39.55 \mathrm{aA}$ & $58.30 \mathrm{aA}$ \\
\hline & \multicolumn{3}{|c|}{ Oct.13 } \\
\hline & FL 50\% & FL 100\% & FL 150\% \\
\hline Irrigated & $32.63 \mathrm{bA}$ & $56.26 \mathrm{aA}$ & $53.16 \mathrm{aA}$ \\
\hline \multirow[t]{3}{*}{ Non-irrigated } & $71.54 \mathrm{aA}$ & $52.42 \mathrm{aA}$ & $46.60 \mathrm{aA}$ \\
\hline & \multicolumn{3}{|c|}{ Dec.13 } \\
\hline & FL 50\% & FL 100\% & FL $150 \%$ \\
\hline Irrigated & $28.16 \mathrm{aB}$ & $57.03 \mathrm{aA}$ & $65.39 \mathrm{aA}$ \\
\hline Non-irrigated & $30.12 \mathrm{aB}$ & $51.77 \mathrm{aA}$ & $31.53 \mathrm{bB}$ \\
\hline
\end{tabular}

In the month of December 2013, irrigated plants showed higher averages of gum production for the higher levels of fertilization: 100 and $150 \%$ (Table 3). Nutrients applied at recommended level (100\%) and excess (150\%) possibly started to increase the content of polysaccharides produced and consequently increased the gum production.

The nut and peduncle production were not affected by treatments, when analyzed independent or by interaction. Submission of dwarf cashew plants to the two factors (water regimes and fertilization levels) for a period of one year is not enough for these plants to present different responses of production.

Oliveira et al (2006), studding the effect of irrigation frequency on cashew nut yield in Northeast Brazil, noticed that irrigation increased nut yield of dwarf cashew clones CCP 76 and CCP 09, but these plants alternated years of high nut yield with years of low yield, even when irrigation was applied. Possibly the difference between the present study and this cited above, for cashew nut production, is the fact these authors used irrigation for a period of six years.

For the variable soluble solids content of the peduncle (SSP), it was observed statistical difference only when the WR factor was evaluated, with values for irrigated superior to those observed for the non-irrigated, 13.5 and 12.5 'Brix, respectively (Figure 2A), without evidence of difference for the FL factor (Figure $2 \mathrm{~B}$ ) or the interaction between the two cited factors. The values were similar:, $12.6,13.3$ and $13.2^{\circ}$ Brix for the use of $50 \%, 100 \%$ and $150 \%$ of the recommended fertilization, respectively (Figure 2B). 

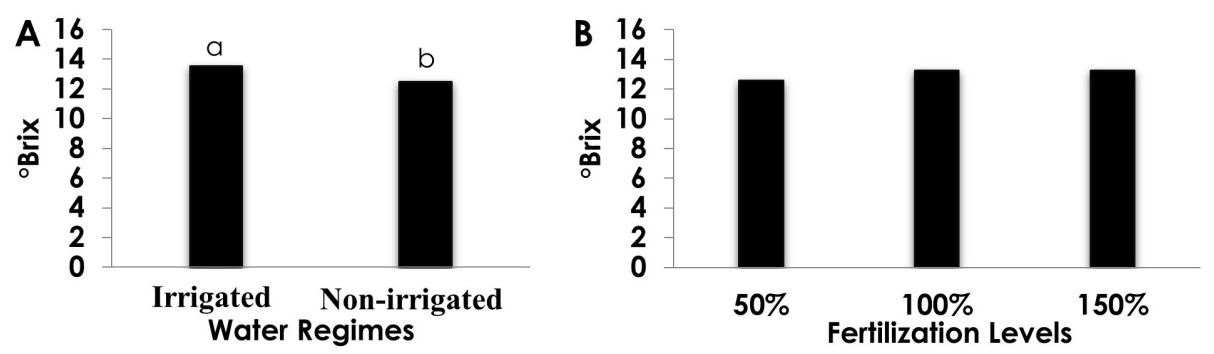

Figure 2. Soluble solids content of peduncle for the 2013 crop season of precocious dwarf cashew, grown under the influence of two water regimes (A) and three fertilization levels (B). Pacajus-CE, Brazil, 2013.

Moreira \& Costa (2013), evaluating the soluble solids content of the cashew peduncle, did not find statistical difference between irrigated and non-irrigated systems, which is not in accordance to the presented in this study.

Nascimento (2010), evaluating the soluble solids content of the pseudofruit, did not observed statistical difference between cultivation systems (irrigated and non-irrigated), information that differs from the data presented in this study. However, it should be noticed that the values observed by the cited author were significant possibly due to the high value of the coefficient of variation.

Since no interaction between factors (WR and FL) for production of nut and peduncle was observed, each of the six treatments were evaluated separately to observe the influence of gum extraction in fruit production, comparing with the control, with no extracted gum(Figure 3). No statistical difference between control and the other treatments was observed, indicating that the gum extraction did not affected the cashew nut and peduncle production.
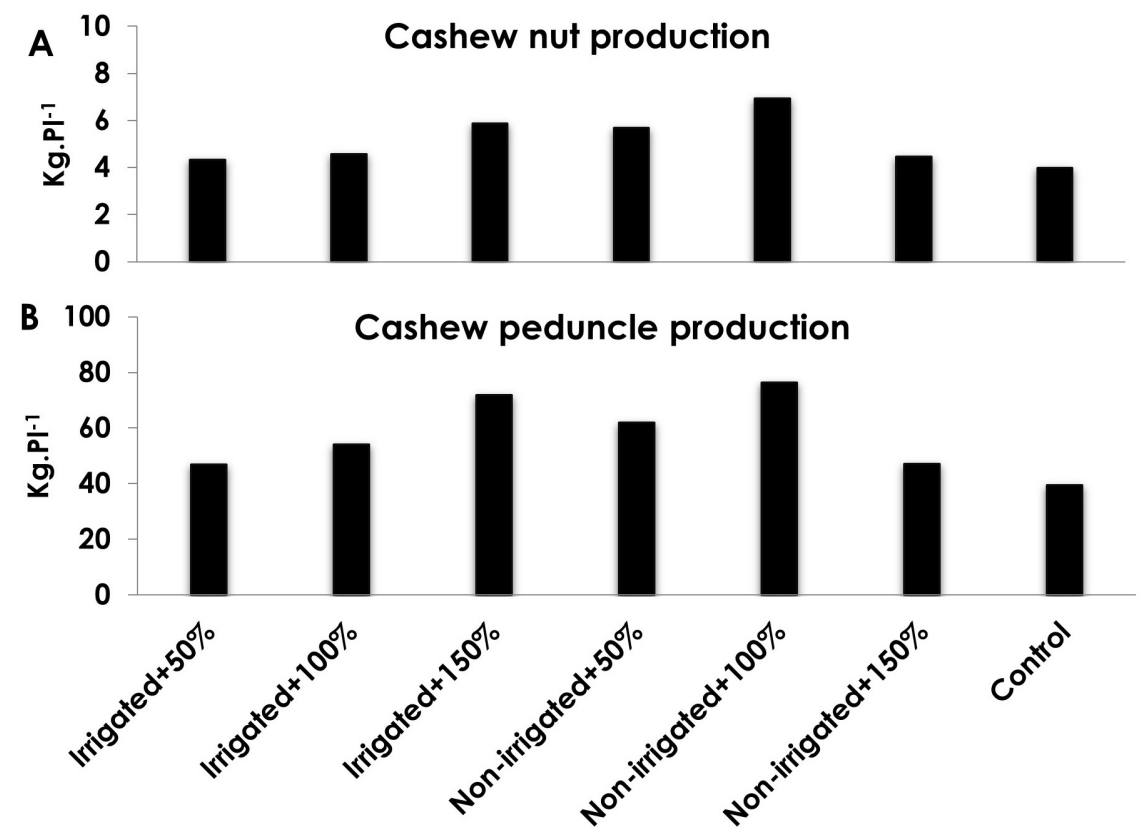

Figure 3. Nut production (A) and peduncle production (B) during the 2013 crop year of dwarf cashew tree, evaluating theseven treatments independently. Pacajus-CE, Brazil, 2013.

Analyzing the average production of nut and peduncle, considering the WR (irrigated or non-irrigated), similar values were found. The cashew nut production was $4.94 \mathrm{~kg} \cdot \mathrm{Pl}^{-1}$ and 5.71 $\mathrm{kg} . \mathrm{Pl}^{-1}$ for irrigated and non-irrigated, respectively and the cashew peduncle production was 57.62 $\mathrm{kg} \cdot \mathrm{Pl}^{-1}$ and $61.83 \mathrm{~kg} \cdot \mathrm{Pl}^{-1}$. The Control showed values of $3.98 \mathrm{~kg} \cdot \mathrm{Pl}^{-1}$ and $39.61 \mathrm{~kg} \cdot \mathrm{Pl}^{-1}$ for nut and peduncle production, respectively (Figure 3 ).

Corroborating to the presented results, 
Amorim et al. (2011) did not observed difference for nut production between irrigated and nonirrigated systems. The author observed values for nut production of 3.0 and $3.3 \mathrm{~kg} \cdot \mathrm{Pl}^{-1}$, respectively.

Nascimento (2010) did not observed difference of nut or peduncle production. The author observed nut production values of 2.73 and $3.41 \mathrm{~kg} \cdot \mathrm{Pl}^{-1}$ and peduncle production of 54.5 and $72 \mathrm{~kg} \mathrm{Pl}^{-1}$ for non-irrigated and irrigated conditions, respectively.

Moreira \& Costa (2013), evaluating the cashew productivity in the Northeast of Brazil, found an increase around $92 \%$ in nut production when compared to irrigated and non-irrigated systems. It should be noticed that in this experiment the plants started to be irrigated with one year before the cropping season, which may explain the non-differentiation of production between the treatments and the divergence with the cited study.

\section{Conclusions}

It is possible the extraction of the cashew gum in the first year without prejudice in the nut and peduncle production.

Gum production in irrigated condition is only promising with the use of higher fertilization levels.

The use of irrigation system in an adult orchard did not influenced the production of fruits (nut and peduncle) during the first year of evaluation.

\section{References}

Adam, I.M., Fadl, E.M. 2011. Determin $\square$ ation of optimum tapping date for gum arabic production in South Kordofan State, Sudan. Journal of Forestry Research 22: 685-688.

Amorim, A.V., Gomes-Filho, E., Bezerra, M.A., Prisco, J.T., Lacerda, C.F. 2011. Produção e fisiologia de plantas de cajueiro anão precoce sob condições de sequeiro e irrigado. Revista Brasileira de Engenharia Agrícola e Ambiental 15:1014-1020.

Bandeira, C. T. 1991. Métodos de preparação da goma de cajueiro. EMBRAPA, Fortaleza, Brasil. 2 p.

Chen, H., Fu, X., Luo, Z. 2015. Effect of gum Arabic on freeze-thaw stability, pasting and rheological properties of tapioca starch and its derivatives. Food Hydrocolloids 51: 355-360.
Crisóstomo, L. A.; Pimentel, C. R. M.; Miranda, F. R. De; Oliveira, V. H. DE. 2009. Cajueiro anão precoce. In: Crisóstomo, L.A., Naumov, A. Fruteiras tropicais do Brasil. Embrapa Agroindústria Tropical, Fortaleza, Brasil. p. 50-69.

Khalid, S.A., Musa, A.M., Saeed, A.M., Abugroun, E.A., Ahmed, E.O.S., Ghalib, M.B., Elnima, E.I., Alkarib, S.Y., Abdelsalam, T.M., Abdelgader, A., Philips, G.O., Philips, A.O. 2014. Manipulating dietary fibre: Gum Arabic making friends of the colon and the kidney. Bioactive Carbohydrates and Dietary Fibre 3: 71-76.

Khaliq, G., Mohamed, M.T.M., Ali, A., Ding, P., Ghazali, H.M. 2015. Effect of gum Arabic coating with calcium chloride on physic-chemical and qualitative properties of mango (Mangifera indica L.) fruit during low temperature storage. Scientia Horticulturae 190:187-194.

Lima, A.C., Santos, R.A., Almeida, F.A.G., Bandeira, C.T. 2011 . Estimulantes químicos na extração da goma de cajueiro (Anacardium occidentale, L.). Ciência Rural 31:409-415.

Lima, M.A., Bezerra, M.A., Gomes Filho, E., Pinto, C. M., Enéas Filho, J. 2010. Trocas gasosas em folhas de sol e sombreadas de cajueiro anão em diferentes regimes hídricos. Revista Ciência Agronômica 41: 654-663.

Melém Junior, N. J.; Fonseca, C. B.; Brito, O. R.; Decaens, T.; Carneiro, M. M.; Matos, M. F. A.; Guedes, M. C.; Queiroz, J. A. L.; Barros, K. O. 2008. Análise de componentes principais para avaliação de resultados analíticos da fertilidade de solos do Amapá. Semina: Ciências Agrárias 29:499-506.

Moreira, O.C., Costa, R.N.T. 2013. Respostas do cajueiro anão precoce a diferentes regimes hídricos. Irriga 18: 223-231.

Mujawamariya, G., Karimov, A.A. 2014. Importance of socio-economic factors in the collection of NTFPs: The case of gum Arabic in Kenya. Forest Policy and Economics 42: 24-29.

Musa, H.H., Ahmed, A.A., Tahua, H.M., Fedail, J.S. 2015. Gum Arabic down-regulate PPAR-Y and SCD mRNA expression in mice. Polish Annals of Medicine 22:11-17.

Nascimento, A.H.C. 2010. Aspectos fisiológicos e produtivos de clones de cajueiro anão precoce cultivado sob dois regimes hídricos. 97f. (Dissertação de Mestrado) - Universidade Federal do Ceará, Fortaleza, Brasil.

Oliveira, V. H. Cajucultura. 2008. Revista Brasileira de Fruticultura 30:1-284, 2008.

Oliveira, V.H, Miranda, F.R., Lima, R.N., Cavalcante, R.R.R. 2006. Effect of irrigation 
frequency on cashew nut yield in Northeast Brazil. Scientia Horticulturae 108:103-407.

Oliveira, V.H., Santos, F.J. de S.; Crisóstomo, L.A.; Saunders, L.C.U. 2003. Manejo da irrigação na produção integrada do cajueiro-anão precoce. (Circular técnica online 15). Embrapa Agroindústria Tropical, Fortaleza, Brasil.

Phillips, G.O., Williams, P.A. 2009. Handbook of Hydrocolloids. CRC Press, Flórida, USA, 948 p.

Vellema, W., Mujawamariya, G., D'Haese, M., Burger, K. 2013. An economic approach to household collection of gum Arabic from the wild. International Forestry Review 15:255-269.

Yang, L., Zhang, L.M. 2009. Chemical structural and chain conformational characterization of some bioactive polysaccharides isolated from natural sources. Carbohydrate Polymers 76:349361. 